\title{
Insulin-induced hypoglycaemia increases plasma concentrations of angiotensin II and does not modify atrial natriuretic polypeptide secretion in man
}

\author{
M. Trovati, P. Massucco, E. Mularoni, F. Cavalot, G. Anfossi, L. Mattiello and G. Emanuelli \\ Cattedra di Clinica Medica Generale e Terapia Medica III, University of Turin, San Luigi Gonzaga Hospital, Turin, Italy
}

\begin{abstract}
Summary. Insulin-induced hypoglycaemia causes profound haemodynamic changes, commonly ascribed to catecholamine increase. The aim of the present study was to investigate the influence of insulin-induced hypoglycaemia on nonadrenergic factors potentially involved in haemodynamic regulation: angiotensin II and alpha-human atrial natriuretic polypeptide. Fourteen healthy male subjects, aged $25.5 \pm 0.74$ years, body mass index $23.81 \pm 0.68 \mathrm{~kg} / \mathrm{m}^{2}$, received (after an overnight fast and at least $60 \mathrm{~min}$ rest in a supine position) an i.v. bolus injection of human regular insulin (Actrapid HM, Novo, Bagsvaerd, Denmark: $3.84 \mathrm{U} / \mathrm{m}^{2}$ ). Serial venous blood samples were drawn in the following $150 \mathrm{~min}$, to measure plasma glucose, angiotensin II, alpha-human natriuretic polypeptide, and factors potentially involved in the regulation of the renin-angiotensinaldosterone system. During the study, we observed a plasma glucose fall, reaching a nadir of $1.95 \pm 0.11 \mathrm{mmol} / 1$ between
\end{abstract}

25 and $30 \mathrm{~min}$, and an increase of angiotensin II (from $7.6 \pm 0.8$ to $13.5 \pm 1.1 \mathrm{pg} / \mathrm{ml}, p=0.01$, quadratic model evaluated by an analysis of the variance for repeated measures), whereas atrial natriuretic polypeptide remained unchanged. As far as the regulation of the renin-angiotensin-aldosterone system is concerned, the increase of angiotensin II is attributable to the increased plasma renin activity, whereas angiotensin converting enzyme was not modified. The increase of plasma renin activity, in turn, is attributable both to the increased catecholamine concentrations and to the decreased potassium levels. Both adrenocorticotropic hormone and angiotensin II are potentially involved in the hypoglycaemiainduced increase of aldosterone concentrations.

Key words: Hypoglycaemia, plasma renin activity, angiotensin II, aldosterone, alpha-human atrial natriuretic polypeptide.
Insulin-induced hypoglycaemia causes profound haemodynamic changes, modifying heart rate, cardiac output, stroke volume, left ventricular ejection fraction, plasma volume, blood pressure and vascular resistances [1-5].

The aim of the present study was to verify whether insulin-induced hypoglycaemia modifies plasma concentrations of two factors potentially involved in some of these changes: angiotensin II and alpha-human atrial natriuretic polypeptide. As is well known, angiotensin II is a potent vasoconstrictor agent [6] produced by the enzymatic cleavage of angiotensin I by angiotensin converting enzyme; angiotensin $I$, in turn, derives from the cleavage of angiotensinogen by renin [7]. It has already been observed that insulin-induced hypoglycaemia causes an increase of plasma renin activity [8-11]. In the present study, the aim was to determine whether hypoglycaemia increases the concentrations of angiotensin II. Throughout the study, we measured also the possible regulating and co-regulating factors of renin, angiotensin II and aldosterone production: namely, plasma potassium, which decreases renin secretion [12] and increases aldosterone release [13]; adrenaline, noradrenaline and cortisol, which stimulate renin secretion $[14,15]$; dopamine, which reduces the concentrations of angiotensin II [16]; angiotensin converting enzyme, which promotes the cleavage of angiotensin I in angiotensin II [7], and adrenocorticotropic hormone (ACTH), which regulates the production of aldosterone [17] and also stimulates renin release [15].

As far as the atrial natriuretic polypeptide is concerned, its different actions have been recently described in detail [18, 19]: briefly, this peptide, produced by mammalian atrial cardiocytes, possesses natriuretic, vasorelaxant and aldosterone inhibiting properties, deeply influencing blood pressure and electrolyte homeostasis; its direct vasorelaxant effect on arterial smooth muscle cells, mediated by cyclic guanosine monophosphate, is reported to antagonise the vasoconstrictor effects of both angiotensin II and noradrenaline; furthermore, atrial natriuretic polypeptide causes a reduction of intravascular volume and a rise of haematocrit. It could, therefore, be involved in the reduction of vascular resistances, diastolic blood pressure and plasma volume [2-5] and in the rise of 


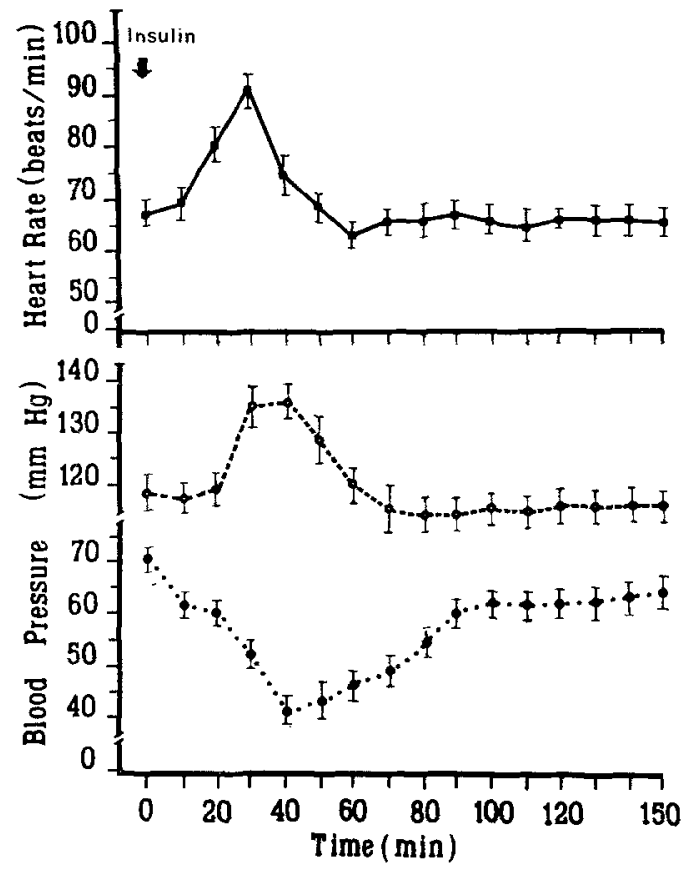

Fig. 1. Influence of hypoglycaemia, induced by an intravenous bolus of human regular insulin $\left(3.84 \mathrm{U} / \mathrm{m}^{2}\right)$ administered at $0 \mathrm{~min}$, on heart rate ( $)(p=0.001$, quadratic model), systolic $(\mathrm{O}-\mathrm{O})$ $(p=0.001$, quadratic model $)$ and diastolic (-- $)(p=0.0001$, quadratic model) blood pressure in 14 healthy subjects.

haematocrit [1] occurring during insulin-induced hypoglycaemia.

\section{Subjects and methods}

Fourteen healthy male volunteers, aged $25.5 \pm 0.74$ years (mean \pm $\mathrm{SEM}$ ), with a body mass index of $23.81 \pm 0.68 \mathrm{~kg} / \mathrm{m}^{2}$, gave their informed consent to participate in the study. They did not take any medication during the three weeks before the study, and were on a weight-maintaining diet without sodium restriction. After an overnight fast and at least $60 \mathrm{~min}$ rest in a supine position, the subjects underwent the studies between 09.30 and 10.00 hours, while in a supine position. The reported investigations have been performed in accordance with the principles of the Declaration of Helsinki, reported in Diabetologia (1978) 15: 431-432

\section{Study A}

The subjects received an i.v. bolus injection of human regular insulin (Actrapid HM, Novo): $3.84 \mathrm{U} / \mathrm{m}^{2}(7.36 \pm 0.17 \mathrm{U}$ ), and were studied both immediately before the i.v. insulin bolus and in the following $150 \mathrm{~min}$. Serial venous blood samples were drawn through an indwelling $n .19$ butterfly needle kept patent with normal saline to determine, at 5-min intervals, plasma glucose (Beckman Glucose Analyzer, Beckman, Fullerton, Calif, USA); at 15-min intervals and as near as possible to the measured hypoglycaemic nadir to determine plasma renin activity (RIA, Kit Sorin, Saluggia, Vercelli, Italy), angiotensin II (RIA, Kit Bühlmann, Shönenbuch, Switzerland, after ethanol extraction), aldosterone (RIA, Kit Ares Serono, Milano, Italy), adrenaline, noradrenaline, and, in 6 subjects, dopamine (high performance liquid chromatography with electrochemical detector, as previously described) [20], ACTH (RIA, Kit Mallinckrodt, Dietzenbach, FRG), cortisol (RIA, Kit Ares Serono), alpha-human atrial
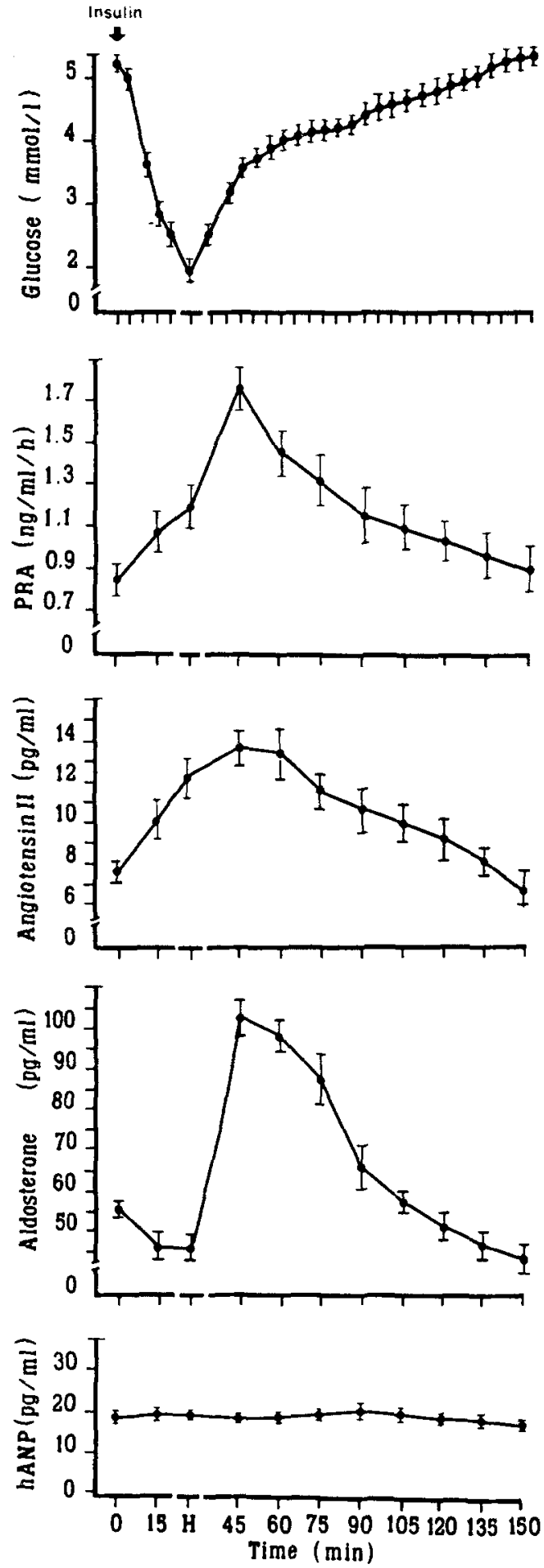

Fig. 2. Influence of hypoglycaemia, induced by an intravenous bolus of human regular insulin $\left(3.84 \mathrm{U} / \mathrm{m}^{2}\right)$ administered at $0 \mathrm{~min}$, on plasma glucose, plasma renin activity (PRA) $(p=0.008$, quadratic model), angiotensin II ( $p=0.01$, quadratic model), aldosterone $(p=0.009$, quadratic model) and alpha-human natriuretic polypeptide (h-ANP) (NS) in 14 healthy subjects. $H$ indicates hypoglycaemic nadir

natriuretic polypeptide (RIA, Kit Peninsula Laboratories, Belmont, Calif, USA, after extraction with $0.1 \%$ trifluoroacetic acid and $60 \%$ acetonitrile), angiotensin converting enzyme (Kit Boehringer-Mannheim, Mannheim, FRG with spectrophotometrical detection of trinitrophenil-glycil-glycine); at 30-min intervals and as near as possible to the measured hypoglycaemic nadir to determine plasma 
Table 1. Influence of hypoglycaemia, induced by an intravenous bolus of human regular insulin $\left(3.84 \mathrm{U} / \mathrm{m}^{2}\right)$ administered at $0 \mathrm{~min}$, on plasma concentrations of factors involved in the regulation of the renin-angiotensin-aldosterone system: potassium ( $p=0.008$, linear model), adrenaline ( $p=0.003$, quadratic model), noradrenaline ( $p=0.004$, quadratic model), dopamine ( $p=0.05$, quadratic model), adrenocorticotropic hormone (ACTH) $(p=0.01$, quadratic model) and cortisol $(p=0.008$, quadratic model) in healthy subjects. Values are expressed as mean \pm SEM. $\mathrm{H}$ indicates hypoglycaemic nadir

\begin{tabular}{|c|c|c|c|c|c|c|c|c|c|c|c|}
\hline Time (min) & 0 & 15 & $\mathrm{H}$ & 45 & 60 & 75 & 90 & 105 & 120 & 135 & 150 \\
\hline $\begin{array}{l}\text { Potassium } \\
(\mathrm{mEg} / 1)\end{array}$ & $\begin{array}{l}4.07 \pm \\
0.06\end{array}$ & & $\begin{array}{l}3.81 \pm \\
0.16\end{array}$ & & $\begin{array}{l}3.64 \pm \\
0.08\end{array}$ & & $\begin{array}{l}3.59 \pm \\
0.04\end{array}$ & & $\begin{array}{l}3.61 \pm \\
0.03\end{array}$ & & $\begin{array}{l}3.64 \pm \\
0.04\end{array}$ \\
\hline $\begin{array}{l}\text { Adrenaline } \\
\text { (pg/ml) }\end{array}$ & $\begin{array}{l}85 \\
35\end{array}$ & $\begin{array}{r}250 \pm \\
40\end{array}$ & $\begin{array}{r}502 \pm \\
71\end{array}$ & $\begin{array}{r}274 \pm \\
65\end{array}$ & $\begin{array}{r}173 \\
64\end{array}$ & $\begin{array}{r}142 \\
43\end{array}$ & $\begin{array}{r}135 \\
37\end{array}$ & $\begin{array}{r}136 \pm \\
42\end{array}$ & $\begin{array}{r}110 \pm \\
39\end{array}$ & $\begin{array}{r}102 \\
31\end{array}$ & $\begin{array}{l}98 \pm \\
22\end{array}$ \\
\hline $\begin{array}{l}\text { Noradrenaline } \\
(\mathrm{pg} / \mathrm{ml})\end{array}$ & $\frac{162}{41} \pm$ & $\begin{array}{r}333 \pm \\
54\end{array}$ & $\begin{array}{r}475 \\
62\end{array}$ & $\begin{array}{r}318 \pm \\
49\end{array}$ & $\begin{array}{r}227 \pm \\
65\end{array}$ & $\begin{array}{r}223 \\
47\end{array}$ & $\begin{array}{r}185 \\
74\end{array}$ & $\begin{array}{r}202 \pm \\
48\end{array}$ & $\begin{array}{c}204 \pm \\
38\end{array}$ & $\begin{array}{r}198 \pm \\
28\end{array}$ & $\begin{array}{r}206 \pm \\
41\end{array}$ \\
\hline $\begin{array}{l}\text { Dopamine } \\
\text { (pg/ml) }\end{array}$ & $\begin{array}{l}95 \\
25\end{array}$ & $\frac{175}{35} \pm$ & $\begin{array}{r}229 \pm \\
51\end{array}$ & $\frac{124}{35} \pm$ & $\begin{array}{l}83 \\
16\end{array}$ & $\begin{array}{l}87 \\
14\end{array}$ & $\begin{array}{l}81 \pm \\
18\end{array}$ & $\begin{array}{l}86 \pm \\
20\end{array}$ & $\begin{array}{l}88 \pm \\
14\end{array}$ & $\begin{array}{l}84 \\
13\end{array} \pm$ & $\begin{array}{l}80 \pm \\
12\end{array}$ \\
\hline $\begin{array}{l}\text { ACTH } \\
\qquad(\mathrm{pg} / \mathrm{ml})\end{array}$ & $\begin{array}{r}12 \pm \\
2\end{array}$ & $\begin{array}{c}18 \pm \\
3\end{array}$ & $\begin{array}{r}23 \\
7\end{array}$ & $\begin{array}{r}46 \pm \\
8\end{array}$ & $\begin{array}{c}24 \\
3\end{array}$ & $\begin{array}{r}20 \pm \\
2\end{array}$ & $\begin{array}{c}18 \pm \\
3\end{array}$ & $\begin{array}{r}12 \pm \\
2\end{array}$ & $\begin{array}{r}10 \pm \\
2\end{array}$ & $\begin{array}{l}9 \pm \\
1\end{array}$ & $\begin{array}{l}9 \pm \\
1\end{array}$ \\
\hline $\begin{array}{l}\text { Cortisol } \\
\text { (ng/ml) }\end{array}$ & $\begin{array}{c}104 \\
8\end{array}$ & $\begin{array}{c}92 \\
8\end{array}$ & $\begin{array}{r}110 \pm \\
10\end{array}$ & $\begin{array}{r}172 \pm \\
8\end{array}$ & $\begin{array}{c}194 \\
11\end{array}$ & $\begin{array}{c}189 \\
13\end{array}$ & $\begin{array}{r}182 \pm \\
7\end{array}$ & $\begin{array}{r}167 \pm \\
12\end{array}$ & $\begin{array}{c}150 \pm \\
13\end{array}$ & $\begin{array}{r}143 \pm \\
11\end{array}$ & $\begin{array}{r}132 \pm \\
7\end{array}$ \\
\hline
\end{tabular}

potassium by flame photometry, and haematocrit by the counter Technicon H 1th System (Technicon Chemicals, Tournai, Belgium). The volumes of blood withdrawn for the samples were promptly replaced with equal volumes of normal saline. Throughout the study, blood pressure was measured by means of a cuff manometer at 5-10 min intervals, and heart rate was recorded at the same time intervals.

\section{Study B}

A control study was carried out on another occasion in randomised order, with the same venous blood samples drawn throughout a 150min saline infusion.

\section{Statistical analysis}

All values are presented as mean \pm SEM. Since the design of experiments consisted of repeated measures of the same parameters over time, an analysis of variance (ANOVA) for repeated measures was applied, using the program BMDP 2V with orthogonal decomposition [21], which also tests the significance of different polynomial models.

\section{Results}

\section{Study $A$}

Plasma glucose showed a basal concentration of $5.16 \pm 0.08 \mathrm{mmol} / 1$. The hypoglycaemic nadir of the different subjects occurred between 25 and $30 \mathrm{~min}$, reaching a mean value of $1.95 \pm 0.11 \mathrm{mmol} / 1$ (Fig. 2). As pictured in Figure 1, we observed throughout the study a significant increase of heart rate $(p=0.001$, quadratic model, indicating the reversibility of the phenomenon), and of systolic blood pressure ( $p=0.001$, quadratic model), whereas diastolic blood pressure significantly decreased ( $p=0.0001$, quadratic model). Throughout the study, haematocrit transiently increased, from $43.9 \pm 0.33 \%$ to $45.3 \pm 0.67 \%$ at the hypoglycaemic nadir and $44.13 \pm 0.56 \%$ at $60 \mathrm{~min}$, with a subsequent return to basal values $(p=0.02$, quadratic model).

As far as the renin-angiotensin-aldosterone system is concerned, Figure 2 shows a significant, reversible increase (quadratic model: $p=0.008, p=0.01$ and $p=0.009$ for plasma renin activity, angiotensin II and aldosterone, respectively). Angiotensin converting enzyme remained unchanged, showing levels of $407 \pm 51,400 \pm 45,380 \pm 31,379 \pm 32$ and $390 \pm 45 \mathrm{U} / 1$ at $0 \mathrm{~min}$, hypoglycaemic nadir, 60,120 and $150 \mathrm{~min}$, respectively. As far as the regulating factors of this system are concerned, Table 1 shows a decrease of plasma potassium ( $p=0.008$, linear model), and a reversible increase (quadratic model) of adrenaline $(p=0.003)$, noradrenaline $(p=0.004)$, dopamine $(p=0.05)$, ACTH $(p=0.01)$ and cortisol $(p=0.008)$.

Alpha-human atrial natriuretic polypeptide remained unchanged (Fig.2).

\section{Study B}

No significant change was observed in the parameters investigated. In particular, angiotensin II concentrations at $0,30,60,90,120$ and $150 \mathrm{~min}$ were: $8.1 \pm 0.8$, $8.0 \pm 0.5, \quad 7.8 \pm 0.8, \quad 8.3 \pm 0.9, \quad 8.2 \pm 0.6, \quad$ and $7.8 \pm 0.7 \mathrm{pg} / \mathrm{ml}$, whereas alpha-human atrial natriuretic polypeptide concentrations at the same time points were: $19 \pm 1.3,20 \pm 1.7,18 \pm 1.5,22 \pm 1.2$, $21 \pm 1.4$, and $19 \pm 1.7 \mathrm{pg} / \mathrm{ml}$.

\section{Discussion}

During insulin-induced hypoglycaemia, we observed an increase in heart rate and systolic blood pressure, a decrease in diastolic blood pressure and a reduction of plasma volume, as indicated by the rise of haematocrit. 
Hypoglycaemia-induced haemodynamic changes are commonly ascribed to adrenaline and noradrenaline. This study shows that other factors also potentially involved in the haemodynamic balance are modified during insulin-induced hypoglycaemia in normal humans.

First at all, this study demonstrates that insulin-induced hypoglycaemia causes a significant increase not only of plasma renin activity, as previously described [8-11], but also of angiotensin II, a peptide with different effects on the haemodynamic and electrolytic regulation. Actually, it is not only a very potent vasoconstrictor agent [6], but also stimulates aldosterone biosynthesis and secretion $[22,23]$, exerts direct effects on renal mesangial [24] and tubular cells [25] modifying the sodium and bicarbonate transport in the proximal convolute tubule $[25,26]$, induces the thirst mechanism [27], enhances the sympathetic tone [28], facilitates the noradrenergic neurotransmission [29] and, finally, shows angiogenetic properties [30]. Furthermore, this study demonstrates that a hypoglycaemia-induced increase of angiotensin II is attributable only to the increased enzymatic cleavage of angiotensinogen to angiotensin I by renin, since angiotensin converting enzyme remained unchanged throughout the test. As far as the regulation of renin increase during hypoglycaemia is concerned, it is likely that the main role is exerted by the enhanced catecholamine concentrations, with a beta-adrenergic mechanism involving cyclic adenosine monophosphate. The hypoglycaemiainduced increase of plasma renin activity is prevented by the beta-adrenergic blockade with propanolol and potentiated by the phosphodiesterase inhibitor theophilline [9]. A possible additive role of the insulin-induced plasma potassium decrease [31] and of the hypoglycaemia-induced ACTH and cortisol increase cannot, however, be ruled out, since these factors are involved in renin secretion $[12,15]$. The decrease in plasma potassium seems to be only an additive factor in the presence of an intact adrenergic system, since the increase in plasma renin activity in dogs during insulin-induced hypoglycaemia also persists when plasma potassium concentrations are kept steady [8]. However, potassium fall could be important in sustaining the plasma renin activity increase in response to hypoglycaemia in the absence of an active adrenergic system, as described in sympathectomised subjects [11]. We have recently observed that the acute potassium fall caused by an insulin infusion reaching and maintaining for $30 \mathrm{~min}$ the concentration of $\sim 160 \mu \mathrm{U} / \mathrm{ml}$ during an euglycaemic insulin clamp causes an increase in plasma renin activity in the absence of any adrenergic activation [32].

As far as the increase in aldosterone is concerned, it must be emphasised that insulin-induced hypoglycaemia is accompanied by changes in the three main regulating factors of aldosterone secretion by the adrenal glomerulosa cells: potassium, ACTH and an- giotensin II [13, 17, 23]. The increase of the first two agonists overcomes the inhibitory effect of the potassium decrease. Since it has been shown that aldosterone release following hypoglycaemia may occur independently of ACTH stimulation [33], the increase of angiotensin II that we demonstrate in this paper seems to be particularly important in sustaining hypoglycaemia-induced aldosterone secretion.

As far as alpha-human atrial natriuretic polypeptide is concerned, no change was detected throughout the study, in agreement with a previous observation showing that this peptide remains unchanged both at the hypoglycaemic nadir and in the following $60 \mathrm{~min}$ [34]. Our study demonstrates that it does not change even in the late recovery phase. This finding could be of relevance, since diastolic blood pressure decreaseindex of vascular resistance fall-persists a long time (Fig. 1). So, the reduction of vascular resistances observed during insulin-induced hypoglycaemia cannot be ascribed to the vasodilatory actions of this peptide. Furthermore, it can be suggested that hypoglycaemia does not modify the atrial distension enough to elicit its secretion. Finally, since it has been observed that noradrenaline can stimulate the release of atrial natriuretic polypeptide [35], the simultaneous measurement of catecholamines in the present study enables us to conclude that the hypoglycaemia-induced increase of noradrenaline does not reach levels able to exert this effect. It is interesting to consider that the lack of atrial natriuretic polypeptide secretion differentiates hypoglycaemia from another condition characterised by similar haemodynamic and hormonal effects, such as acute physical exercise [36].

In conclusion, the profound haemodynamic changes caused by insulin-induced hypoglycaemia are due to the dynamic interaction between the vasoconstrictor and the vasodilating effects exerted by different factors in different areas, with regional variations of blood flow [5, 37]. Catecholamines certainly play an essential role in these phenomena, both directly and indirectly, since they regulate the secretion of non adrenergic agents potentially involved in haemodynamic changes, such as angiotensin II. Among catecholamines, we observed also an increase of dopamine, which confirms its release under stress conditions [38]. The physiological role of circulating dopamine needs further investigation. Recent studies performed using agonists and antagonists of specific dopamine receptors suggest, however, that dopamine is not only a cerebral neurotransmitter, but also plays a physiological role in blood pressure regulation, with direct and indirect vasodilating effects exerted mainly in the coronaric, mesenteric, renal and cerebral vascular districts [39]. The role of dopamine in hypoglycaemia-induced vasodilation needs to be further evaluated, whereas alpha-human atrial natriuretic polypeptide is certainly not implicated in this haemodynamic phenomenon. 
Acknowledgements. We are particularly grateful to Dr. G. Rocca for the statistical evaluation of data. This work was supported by a grant of the Italian Department of Education.

\section{References}

1. Frier BM, Corrall RJM, Davidson NMcD, Webber RG, Dewar A, French EB (1983) Peripheral blood cell changes in response to acute hypoglycaemia in man. Eur $\mathbf{J}$ Clin Invest 13: 33-39

2. Hilsted J, Bonde-Petersen F, Norgaard MB, Greniam M, Christiansen NJ, Parving HH, Suzuki M (1984) Haemodynamic changes in insulin-induced hypoglycaemia in normal man. Diabetologia $26: 328-332$

3. Neil HAW, Gale EAM, Hamilton SJC, Lopez-Espinoza I, Kaura R, Mac Carthy ST (1987) Cerebral blood flow increases during insulin-induced hypoglycaemia in Type I (insulin-dependent) diabetic patients and control subjects. Diabetologia 30 : 305-309

4. Fisher BM, Gillen G, Dargie HJ, Inglis GC, Frier MB (1987) The effects of insulin-induced hypoglycaemia on cardiovascular function in normal man: studies using radionuclide ventriculography. Diabetologia 30: 841-845

5. Wiles PG, Grant PJ, Stickland MH, Dean HG, Wales JK, Davies JA (1988) Regional variation in skin blood flow response to hypoglycaemia in Type 1 (insulin-dependent) diabetic patients without complications. Diabetologia 31: 98-102

6. Devynck MA, Meyer P (1976) Angiotensin receptors in vascular tissue. Am J Med 61: 758-767

7. Campbell DJ (1987) Circulating and tissue angiotensin system. J Clin Invest 79: 1-6

8. Otsuka K, Assaykeen TA, Goldfien A, Ganong WF (1970) Effect of hypoglycaemia on plasma renin activity in dogs. Endocrinology 87: 1306-1317

9. Lowder SC, Frazer MG, Liddle GW (1975) Effect of insulin-induced hypoglycaemia upon plasma renin activity in man. J Clin Endocrinol Metab 41: 97-105

10. Lilienfeld-Toal HV, Mackes KG, Laudage G, Willms B (1976) Plasma AMP and renin in diabetics during insulin-induced hypoglycaemia. Horm Metab Res 8: 491

11. Frier BM, Corrall RJM, Pritchard JL, Sever PS (1981) Changes in plasma renin activity after hypoglycaemia in sympathectomized man. Clin Sci 61: 245-247

12. Brunner HR, Baer L, Sealey JE, Ledingham JGG, Laragh JH (1970) The influence of potassium administration and of potassium deprivation on plasma renin in normal and hypertensive subjects. J Clin Invest 49: 2128-2138

13. Gann DS, Delea CS, Gill JR, Thomas JP, Bartter FC (1964) Control of aldosterone secretion by change of body potassium in normal man. Am J Physiol 207: 104-108

14. Davies R, Slater JDH (1976) Is the adrenergic control of renin release dominant in man? Lancet II: 594-596

15. Davis JD, Freeman RH (1976) Mechanisms regulating renin release. Physiol Rev 56:1-56

16. Connell JMC, Tonolo G, Davies DL, Finlayson J, Ball SG, Inglis G, Fraser R (1987) Dopamine affects angiotensin II-induced steroidogenesis by altering clearance of the peptide in man. J Endocrinol 113: 139-146

17. Kaplan NM, Bartter FC (1962) The effect of ACTH, renin, angiotensin II, and various precursors on biosynthesis of aldosterone by adrenal slices. J Clin Invest 41: 715-724

18. Laragh JH (1985) Atrial natriuretic hormone, the renin-aldosterone axis, and blood pressure-electrolyte homeostasis. N Engl J Med 313: $1330-1340$

19. Weidmann $P$, Hasler $R$, Gnädinger MP, Lang RE, Uehlinger DE, Shaw S, Rascher W, Reubi FC (1986) Blood levels and renal effects of atrial natriuretic peptide in normal man. J Clin Invest $77: 734-742$
20. Trovati M, Anfossi G; Cavalot F, Vitali S, Massucco P, Mularoni E, Schinco PC, Tamponi G, Emanuelli G (1986) Studies on mechanisms involved in hypoglycaemia-induced platelet activation. Diabetes 35: 818-825

21. BMDP (1981) In: Statistical software Inc. University of California Press, Los Angeles, USA, pp 359-412

22. Dufau ML, Klinman B (1968) Pharmacologic effects of angiotensin II-amide on aldosterone and corticosterone secretion by the intact anesthetized rat. Endocrinology 82: 29-36

23. Douglas J, Aguilera G, Kondo T, Catt KJ (1978) Angiotensin II receptors and aldosterone production in rat adrenal glomerulosa cells. Endocrinology 102: 685-696

24. Ausiello DA, Kreisberg JI, Roy C, Karnovsky MJ (1980) Contraction of cultured rat glomerular mesangial cells after stimulation with angiotensin II and arginine vasopressin. J Clin Invest 65: 754-760

25. Schuster VL, Kokko JP, Jacobson HR (1984) Angiotensin II directly stimulates sodium transport in rabbit proximal convolutes tubules. J Clin Invest 73: 507-515

26. Liu FY, Cogan MG (1987) Angiotensin II: a potent regulator of acidification in the rat early proximal convolute tubule. J Clin Invest $80: 272-275$

27. Fitzsimons JT (1978) Angiotensin, thirst, and sodium appetite: retrospect and prospect. Fed Proc 37: 2669-2675

28. Buckley JP, Jandhyala BS (1977) Central cardiovascular effects of angiotensin. Life Sci 1485-1494

29. Zimmerman BG (1978) Actions of angiotensin on adrenergic nerve endings. Fed Proc 37: 199-202

30. Fernandez LA, Twickler J, Mead A (1985) Neovascularization produced by angiotensin II. J Lab Clin Med 105: 141-145

31. Andres R, Baltzan MA, Cader G, Zierler KL (1962) Effect of insulin on carbohydrate metabolism and on potassium in the forearm of man. J Clin Invest 41: 108-115

32. Trovati M, Cavalot F, Massucco P, Anfossi G, Mularoni E, Emanuelli $G$ (1988) Insulin increases angiotensin II concentrations in man. Diabetologia 31: $551 \mathrm{~A}$

33. Frier BM, Al-Dujaili EAS, Corrall RJM, Pritchard JL, Edwards CRW (1984) Autonomic neural control mechanism and the release of adrenal steroids after hypoglycaemia. Horm Metab Res 16 [Suppl] 138-141

34. Fisher BM, Baylis PH, Frier BM (1987) Plasma oxytocin, arginine vasopressin and atrial natriuretic peptide responses to insulin-induced hypoglycaemia in man. Clin Endocrinol 26: 179-185

35. Uehlinger DE, Weidmann $P$, Gnaedinger MP, Shaw S, Lang RE (1986) Depressor effects and release of atrial natriuretic peptide during norepinephrine and angiotensin II infusion in man. J Clin Endocrinol Metab 63: 674-699

36. Somers VK, Anderson JV, Conway J, Sleight P, Bloom SR (1986) Atrial natriuretic peptide is released by dynamic exercise in man. Horm Metab Res 18: 871-872

37. Frier BM, Hilsted J (1985) Does hypoglycaemia aggravate the complications of diabetes? Lancet II: 1175-1177

38. Woolf PD, Akowuah ES, Lee L, Kelly M, Feibel J (1983) Evaluation of the dopamine response to stress in man. J Clin Endocrinol Metab 56: 246-250

39. Goldberg LI, Rajfer SI (1985) Dopamine receptors: applications in clinical cardiology. Circulation 72: 245-248

Received: 13 June 1988

and in revised form: 6 September 1988

Prof. M.Trovat

Cattedra di Clinica Medica Generale e Terapia Medica

dell' Universita' di Torino

Ospedale San Luigi Gonzaga

I-10043 Orbassano (Torino)

Italy 